\title{
Interpreting global trends in type 2 diabetes complications and mortality
}

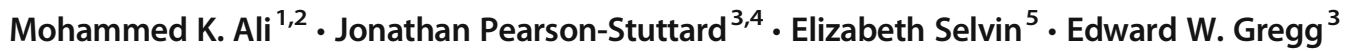

Received: 13 May 2021 / Accepted: 3 August 2021 / Published online: 27 November 2021

(C) The Author(s) 2021

\begin{abstract}
International trends in traditional diabetes complications (cardiovascular, renal, peripheral vascular, ophthalmic, hepatic or neurological diseases) and mortality rates are poorly characterised. An earlier review of studies published up to 2015 demonstrated that most data come from a dozen high-income countries (HICs) in North America, Europe or the Asia-Pacific region and that, in these countries at least, rates of acute glycaemic fluctuations needing medical attention and amputations, myocardial infarction and mortality were all declining over the period. Here, we provide an updated review of published literature on trends in type 2 diabetes complications and mortality in adults since 2015. We also discuss issues related to data collection, analysis and reporting that have influenced global trends in type 2 diabetes and its complications. We found that most data on trends in type 2 diabetes, its complications and mortality come from a small number of HICs with comprehensive surveillance systems, though at least some lowand middle-income countries (LMICs) from Africa and Latin America are represented in this review. The published data suggest that HICs have experienced declines in cardiovascular complication rates and all-cause mortality in people with diabetes. In parallel, cardiovascular complications and mortality rates in people with diabetes have increased over time in LMICs. However, caution is warranted in interpreting trends from LMICs due to extremely sparse data or data that are not comparable across countries. We noted that approaches to case ascertainment and definitions of complications and mortality (numerators) and type 2 diabetes (the denominator) vary widely and influence the interpretation of international data. We offer four key recommendations to more rigorously document trends in rates of type 2 diabetes complications and mortality, over time and worldwide: (1) increasing investments in data collection systems; (2) standardising case definitions and approaches to ascertainment; (3) strengthening analytical capacity; and (4) developing and implementing structured guidelines for reporting of data.
\end{abstract}

Keywords Data quality $\cdot$ Diabetes complications $\cdot$ High-income countries $\cdot$ Low- and middle-income countries $\cdot$ Mortality · Review · Trends

Mohammed K. Ali

mkali@emory.edu

Edward W. Gregg

egregg@ic.ac.uk

1 Hubert Department of Global Health, Rollins School of Public Health, Emory University, Atlanta, GA, USA

2 Department of Family and Preventive Medicine, School of Medicine, Emory University, Atlanta, GA, USA

3 Department of Epidemiology and Biostatistics, School of Public Health, Imperial College, London, UK

4 Health Analytics, Lane Clark \& Peacock LLP, London, UK

5 Department of Epidemiology, Johns Hopkins Bloomberg School of Public Health, Baltimore, MD, USA

\begin{abstract}
Abbreviations
HIC High-income country

LMIC Low- and middle-income country
\end{abstract}

\section{Introduction}

Over the past four decades, the number of adults living with diabetes mellitus worldwide has increased fourfold from 108 million in 1980 to 463 million in 2019 [1, 2]. An estimated 90-95\% of these cases are type 2 diabetes. Both type 1 and type 2 diabetes have far-reaching effects on the health and economies of communities. Quantifying how type 2 diabetes complications and mortality rates have changed is an important aspect of monitoring the impact of diabetes and potential 
policy, programmes and clinical interventions being implemented worldwide. However, data regarding international trends in type 2 diabetes-related complications and mortality are scarce. A previous review aggregated data published up to 2015 on cardiovascular, renal, ophthalmic and acute complications and documented the scarcity of data, describing trends observed in the few countries where published data were available [3].

Here, we compiled the published literature to assess whether newer and more widespread data have emerged since 2015 and what the literature showed. We examine and offer perspectives on a range of potential methodological variations and biases that may explain the observed international trends in type 2 diabetes complications and mortality. Our review focuses on adults with type 2 diabetes, as the pathophysiology, age of onset and progression for type 1 diabetes are quite distinct. We discuss interpretations of these data and propose recommendations that could help improve and harmonise our understanding of the impacts of type 2 diabetes within and across countries.

\section{Global diabetes complications and mortality: the current evidence}

We searched the National Library of Medicine database in March 2021 for articles that reported trends in rates of diabetesrelated complications or mortality in adults across different geographical regions. We included articles that reported data with international, national or subnational coverage. We included studies with high-quality data sources such as registries or discharge records and excluded purely modelled estimates $[4,5]$. We extracted information and tabulated the countries that were represented, definitions of the denominators and numerators used and a summary of the direction of trends.

The included studies were published during 2015-2021 and were from relatively few countries, the most common being highincome countries (HICs) in Europe, North America and Australasia. The few low- and middle-income countries (LMICs) represented were Ghana and South Africa (Africa), Brazil, Colombia and Argentina (Latin America) and China (Asia). Two articles used the WHO mortality database $[6,7]$ from approximately 108 countries to report on all-cause and causespecific mortality trends over 15 years, providing a more global perspective. Most of the studies did not distinguish between diabetes type (type 1, type 2 or other forms of diabetes). The data were generally limited to age- and sex-specific rates, with few, if any, studies examining trends in rates by socioeconomic status. Very few studies from countries with diverse populations provided results according to race/ethnicity.

Data for rates of diabetes complications (Table 1) published between 2016-2021 were predominantly from HICs. Patterns show declining rates of hospitalisation for vascular complications and acute glycaemic fluctuations over time, especially in the

\section{Key recommendations}

\section{- Increase LMIC data}

- Standardise definitions

- Strengthen analytical capacity

- Encourage use of reporting guidelines

decade after 2005. Lower-extremity amputations increased over this period, driven by toe and minor amputations, with declines in major and higher limb amputations. The only middle-income country represented was Brazil, where diabetes-related hospitalisations in the overall population increased over 2008 2019. There were no data on diabetic kidney disease or ophthalmic, hepatic or neurological diseases over time.

Mortality trends in diabetes are typically documented using two methods: (1) population-based sources where cause-specific mortality rates are estimated among people with diabetes who participated in population registries or other administrative datasets or cohort studies and (2) estimates of deaths in the general population where diabetes was recorded on death certificates as the underlying cause or a contributing cause (Table 2). Global data from the WHO [6, 7] and data from some LMICs [8-10] were derived from death certificates, and these showed increasing mortality due to diabetes over time. Meanwhile, data from HICs mostly concerned mortality rates in people with diabetes from population-based sources (e.g. registries or administrative data sources), and these tended to show declines, especially after 2000. Other findings from HICs included less-pronounced declines in mortality rates in adults under the age of 45 years $[11,12]$, more marked declines in cardiovascular causes of death and increased or stable death rates due to infectious causes such as pneumonia $[13,14]$.

In countries with diverse race/ethnic populations, an extensive literature has documented how underrepresented race/ethnic or indigenous groups tend to experience higher rates and disproportionate burdens of diabetes complications and mortality [15]. In our review, we noted persistently higher mortality rates in Māori New Zealanders than in their white counterparts [16]. Certain race/ethnic groups are also more likely to experience adverse socioeconomic circumstances and barriers to healthcare access. Some ethnic groups, especially Pacific Islanders and Native Americans, appear to have physiologically higher risk of type 2 diabetes and renal complications [17], but these groups represent very small segments of national datasets, meaning the estimates are imprecise. This suggests that studies dedicated to understanding biological risk are necessary to improve our efforts to address diabetes globally. 
Table 1 Recent (2015 to 2021) publications with population-based data regarding trends in diabetes complications

\begin{tabular}{|c|c|c|c|c|c|c|}
\hline Country & Study & $\begin{array}{l}\text { Years of } \\
\text { data }\end{array}$ & Data & Denominator & Numerator & Findings \\
\hline USA & Cai [51] & 2008-2018 & $\begin{array}{l}\text { Veterans Affairs } \\
\text { database }\end{array}$ & $\begin{array}{l}\text { Veterans } \\
\qquad(6,493,14- \\
1)\end{array}$ & Incidence of LEA & $\begin{array}{l}\text { Increased overall ( } 12.9 \text { to } 18.1 \text { per } 10,000 \\
\text { individuals) but declined in women } \\
62 \% \text { of the increase was in toe amputations }\end{array}$ \\
\hline USA & An [52] & 2003-2014 & $\begin{array}{l}\text { Kaiser } \\
\text { Permanente } \\
\text { database }\end{array}$ & $\begin{array}{l}\text { Incident } \\
\text { T2DM } \\
\text { cases } \\
(135,199)\end{array}$ & $\begin{array}{l}\text { Incidence of } 13 \\
\text { complications and } \\
\text { all-cause mortality }\end{array}$ & $\begin{array}{l}\text { 5-year incidence rates declined over time } \\
\text { Neuropathy, CKD and CVD were the most } \\
\text { common complications }\end{array}$ \\
\hline Spain & $\begin{array}{l}\text { López-de-Andrés } \\
\text { [53] }\end{array}$ & 2001-2018 & $\begin{array}{l}\text { National } \\
\text { hospital } \\
\text { discharge } \\
\text { database }\end{array}$ & $\begin{array}{l}\text { People with } \\
\text { DM }\end{array}$ & $\begin{array}{l}\text { UTI hospitalisation and } \\
\text { in-hospital mortality }\end{array}$ & $\begin{array}{l}\text { From } 2001-2003 \text { to } 2016-2018 \text { admissions per } \\
100,00 \text { individuals increased from } 290.8 \text { to } \\
568.5 \text { for DM and } 74.8 \text { to } 144.0 \text { for non-DM } \\
\text { In-hospital mortality declined over time }\end{array}$ \\
\hline Spain & $\begin{array}{l}\text { Orozco-Beltrán } \\
\text { [54] }\end{array}$ & 2005-2015 & $\begin{array}{l}\text { National } \\
\text { hospital } \\
\text { discharge } \\
\text { database }\end{array}$ & $\begin{array}{l}\text { People with } \\
\text { DM }\end{array}$ & $\begin{array}{l}\text { Hospitalisation due to } \\
\text { hypoglycaemia and } \\
\text { mortality }\end{array}$ & $\begin{array}{l}\text { Admissions per } 100,000 \text { individuals decreased } \\
\text { from } 21.5 \text { to } 13.2 \text { in women and from } 30.2 \text { to } \\
23.7 \text { in men } \\
\text { Mortality (per } 100,000 \text { individuals) declined } \\
\text { from } 8.6 \text { to } 4.1 \text { in women and from } 9.4 \text { to } 6.4 \\
\text { in men }\end{array}$ \\
\hline Portugal & Ramalho [55] & 2016-2017 & $\begin{array}{l}\text { National quality } \\
\text { improvement } \\
\text { registry }\end{array}$ & $\begin{array}{l}\text { People with } \\
\text { DM }\end{array}$ & $\begin{array}{l}\text { Preventable } \\
\text { hospitalisations }\end{array}$ & $\begin{array}{l}\text { Decreased from } 79 \text { to } 65.2 \text { per } 100,000 \\
\text { individuals }\end{array}$ \\
\hline $\begin{array}{l}\text { South } \\
\quad \text { Korea }\end{array}$ & Park [56] & $2006-2015$ & $\begin{array}{l}\text { National health } \\
\text { insurance } \\
\text { database }\end{array}$ & $\begin{array}{l}\text { People with } \\
\text { DM }\end{array}$ & $\begin{array}{l}\text { Hospitalisation due to } \\
\text { vascular } \\
\text { complications and } \\
\text { mortality }\end{array}$ & $\begin{array}{l}\text { CVD events declined; hospitalisations due to } \\
\text { CHF (per 10,000 individuals) increased } \\
\text { from } 124 \text { to } 161 \text { in women and from } 72 \text { to } \\
146 \text { in men; hospitalisations for PAD (per } \\
10,000 \text { individuals) increased from } 19 \text { to } 35 \\
\text { in women and from } 39 \text { to } 55 \text { in men } \\
\text { Mortality from cancers, CVD, DM and HTN } \\
\text { declined but mortality from pneumonia } \\
\text { increased }\end{array}$ \\
\hline $\begin{array}{l}\text { South } \\
\text { Korea }\end{array}$ & You [57] & 2004-2013 & $\begin{array}{l}\text { National health } \\
\text { insurance } \\
\text { database }\end{array}$ & Population & $\begin{array}{l}\text { Hospitalisation due to } \\
\text { hyperglycaemia and } \\
\text { in-hospital mortality }\end{array}$ & $\begin{array}{l}\text { 2004-2006: increased ( } 1.8 \text { to } 2.6 \text { per } 1000 \\
\text { individuals) } \\
\text { 2007-2013: decreased ( } 2.5 \text { to } 2.2 \text { per } 1000 \\
\text { individuals) } \\
\text { Mortality declined }\end{array}$ \\
\hline $\begin{array}{l}\text { South } \\
\quad \text { Korea }\end{array}$ & $\operatorname{Kim}[58]$ & 2011-2016 & $\begin{array}{l}\text { National health } \\
\text { insurance } \\
\text { database }\end{array}$ & $\begin{array}{l}\text { People with } \\
\text { diabetic } \\
\text { foot }\end{array}$ & $\begin{array}{l}\text { LEA and } \\
\text { revascularisation }\end{array}$ & $\begin{array}{l}\text { Total LEAs increased with flat/declining major } \\
\text { amputations; revascularisation interventions } \\
\text { increased }\end{array}$ \\
\hline $\begin{array}{l}\text { Hong } \\
\text { Kong }\end{array}$ & $\mathrm{Wu}[59]$ & 2001-2016 & $\begin{array}{l}\text { Electronic } \\
\text { medical } \\
\text { record } \\
\text { diabetes } \\
\text { registry }\end{array}$ & $\begin{array}{l}\text { People with } \\
\text { DM } \\
(770,078)\end{array}$ & Hospitalisation for LEA & $\begin{array}{l}\text { Decreased (per } 10,000 \text { individuals) for minor } \\
\text { LEAs (from } 14.0 \text { to } 7.2 \text { in men }[-48.6 \%] \\
\text { and from } 7.9 \text { to } 3.2 \text { in women }[-59.5 \%] \text { ) and } \\
\text { major LEAs (from } 19.5 \text { to } 4.3 \text { in men } \\
{[-77.9 \%] \text { and from } 11.6 \text { to } 2.4 \text { in women }} \\
{[-79.3 \%] \text { ) }} \\
\text { Similar findings for newly diagnosed DM and } \\
\text { T1DM }\end{array}$ \\
\hline Taiwan & Lin [60] & $2007-2014$ & $\begin{array}{l}\text { National health } \\
\text { insurance } \\
\text { database }\end{array}$ & $\begin{array}{l}\text { People with } \\
\text { T2DM }\end{array}$ & $\begin{array}{l}\text { Diabetic foot } \\
\text { complications (ulcers, } \\
\text { infections, gangrene, } \\
\text { PAD hospitalisation) }\end{array}$ & $\begin{array}{l}\text { Decreased LEAs ( } 2.9 \text { to } 2.1 \text { per } 1000 \\
\text { individuals) } \\
\text { Major LEAs declined from } 56.2 \% \text { to } 47.4 \% \text { of } \\
\text { all LEAs }\end{array}$ \\
\hline Brazil & Florêncio [61] & 2008-2019 & $\begin{array}{l}\text { National } \\
\text { hospital } \\
\text { registry }\end{array}$ & Population & $\begin{array}{l}\text { Hospitalisation related } \\
\text { to DM }\end{array}$ & $\begin{array}{l}\text { Increased hospitalisations, higher in female } \\
\text { sex; variation in mortality by region }\end{array}$ \\
\hline
\end{tabular}

The literature included is composed of articles that reported data with international, national or at least subnational coverage and data sources such as registries or administrative/discharge records. This table does not include publications up to 2015 and is intended as an update to prior reviews [3] CHF, congestive heart failure; CKD, chronic kidney disease; DM, diabetes mellitus; HTN, hypertension; LEA, lower-extremity amputation; PAD, peripheral arterial disease; T1DM, type 1 diabetes mellitus; T2DM, type 2 diabetes mellitus 
Table 2 Recent (2015 to 2021) publications with population-based data regarding trends in mortality in adults with diabetes

\begin{tabular}{|c|c|c|c|c|c|c|}
\hline Country & Study & Year & Data & Denominator & Numerator & Findings \\
\hline Brazil & Malhão [8] & 1980-2012 & $\begin{array}{l}\text { National vital } \\
\text { statistics } \\
\text { registry }\end{array}$ & Population & $\begin{array}{l}\text { Age-standardised } \\
\text { mortality }\end{array}$ & $\begin{array}{l}\text { Increased (per } 100,000 \text { individuals) } \\
\text { from } 20.8 \text { to } 47.6 \text { in men and } \\
\text { from } 28.7 \text { to } 47.2 \text { in women } \\
\text { Largest increases were seen up to } \\
\text { 2003-2005, then plateaued }\end{array}$ \\
\hline Brazil & Klafke [62] & 1991-2010 & $\begin{array}{l}\text { National vital } \\
\text { statistics } \\
\text { registry }\end{array}$ & Population & $\begin{array}{l}\text { Age-standardised } \\
\text { mortality (all-cause } \\
\text { and due to acute } \\
\text { complications) }\end{array}$ & $\begin{array}{l}\text { Decreased from } 8.4 \text { to } 2.5 \text { per } \\
100,000 \text { individuals }\end{array}$ \\
\hline Colombia & $\begin{array}{l}\text { Chaparro-Narváez } \\
\text { [63] }\end{array}$ & 1979-2017 & $\begin{array}{l}\text { National vital } \\
\text { statistics } \\
\text { registry }\end{array}$ & Population & $\begin{array}{l}\text { Age-standardised } \\
\text { mortality }\end{array}$ & $\begin{array}{l}\text { 1979-1999: increased (per } 100,000 \\
\text { individuals) from } 13.2 \text { to } 26.6 \text { in } \\
\text { women and from } 10.1 \text { to } 22.7 \text { in } \\
\text { men } \\
\text { 1999-2017: decreased (per } 100,000 \\
\text { individuals) from } 2.6 \text { to } 15.4 \text { in } \\
\text { women and from } 22.7 \text { to } 15.9 \text { in } \\
\text { men }\end{array}$ \\
\hline Argentina & Hernández [64] & 1990-2013 & $\begin{array}{l}\text { National vital } \\
\text { statistics } \\
\text { registry }\end{array}$ & Population & $\begin{array}{l}\text { Age-standardised } \\
\text { mortality }\end{array}$ & $\begin{array}{l}\text { 1990-2001: increased } \\
\text { 2002-2013: decreased } \\
\text { Greater declines in women } \\
\text { Higher mortality over age } 50\end{array}$ \\
\hline Ghana & $\begin{array}{l}\text { Sarfo-Kantanka } \\
\quad[10]\end{array}$ & 1983-2014 & $\begin{array}{l}\text { Tertiary } \\
\text { referral } \\
\text { hospital } \\
\text { (central } \\
\text { Ghana) }\end{array}$ & $\begin{array}{l}\text { People with DM } \\
\quad(11,414)\end{array}$ & In-hospital mortality & $\begin{array}{l}\text { Increased from } 7.6 \text { to } 30.0 \text { per } 1000 \\
\text { deaths }\end{array}$ \\
\hline $\begin{array}{l}\text { South } \\
\text { Africa }\end{array}$ & Nojilana [9] & 1997-2010 & $\begin{array}{l}\text { National vital } \\
\text { statistics } \\
\text { registry }\end{array}$ & $\begin{array}{l}\text { Deaths in } 2010 \\
(594,071)\end{array}$ & Cause-specific mortality & $\begin{array}{l}\text { Increased to } 52 \text { per } 100,000 \text { deaths } \\
\text { Lower for White vs other groups }\end{array}$ \\
\hline UK & $\begin{array}{l}\text { Pearson-Stuttard } \\
\quad[13]\end{array}$ & 2011-2018 & $\begin{array}{l}\text { National } \\
\text { primary care } \\
\text { database }\end{array}$ & $\begin{array}{l}\text { People with DM } \\
\quad(313,907)\end{array}$ & $\begin{array}{l}\text { Age-standardised } \\
\text { mortality (all-cause } \\
\text { and DM-specific) }\end{array}$ & $\begin{array}{l}\text { Decline in all-cause mortality in } \\
\text { those with DM }(31-32 \%) \text {; similar } \\
\text { decline in non-DM } \\
\text { Cause-specific declines except for } \\
\text { dementia and liver disease }\end{array}$ \\
\hline USA & Gregg [11] & $\begin{array}{r}1988-1994 \text { to } \\
2010-2015\end{array}$ & $\begin{array}{l}\text { National } \\
\quad \text { surveys } \\
\text { linked to } \\
\text { vital } \\
\text { statistics }\end{array}$ & $\begin{array}{l}\text { People with and } \\
\text { without DM }\end{array}$ & $\begin{array}{l}\text { Age-standardised } \\
\text { mortality (all-cause } \\
\text { and DM-specific) }\end{array}$ & $\begin{array}{l}\text { All-cause mortality (per } 1000 \\
\text { person-years) declined from } \\
23.1 \text { to } 15.2 \\
\text { More marked declines for vascular, } \\
\text { then cancer deaths } \\
\text { No decline in those aged } \\
<45 \text { years }\end{array}$ \\
\hline China & $\operatorname{Li}[65]$ & 2003-2012 & $\begin{array}{l}\text { National vital } \\
\text { statistics } \\
\text { registry }\end{array}$ & Population & $\begin{array}{l}\text { Age-standardised } \\
\text { mortality }\end{array}$ & $\begin{array}{l}\text { Decreasing } \\
\text { More marked in urban populations }\end{array}$ \\
\hline $\begin{array}{l}\text { Hong } \\
\text { Kong }\end{array}$ & $\mathrm{Wu}[12]$ & 2001-2016 & $\begin{array}{l}\text { Electronic } \\
\text { medical } \\
\text { record } \\
\text { diabetes } \\
\text { registry }\end{array}$ & $\begin{array}{l}\text { People with DM } \\
\quad(390,071 \text { men, } \\
380,007 \text { women })\end{array}$ & $\begin{array}{l}\text { Age-standardised } \\
\text { mortality (all-cause } \\
\text { and DM-specific) }\end{array}$ & $\begin{array}{l}\text { All-cause mortality declined (per } \\
100,000 \text { individuals) from } 3.3 \text { to } \\
1.7 \text { in women and from } 2.8 \text { to } 1.5 \\
\text { in men } \\
\text { No decline in those aged }<45 \text { years }\end{array}$ \\
\hline Taiwan & $\operatorname{Li}[66]$ & 2005-2014 & $\begin{array}{l}\text { National health } \\
\text { insurance } \\
\text { linked to } \\
\text { vital } \\
\quad \text { statistics }\end{array}$ & People with DM & $\begin{array}{l}\text { Age-standardised } \\
\text { mortality (all-cause } \\
\text { and DM-specific) }\end{array}$ & $\begin{array}{l}\text { All-cause mortality declined (per } \\
100,000 \text { individuals) from } 3.1 \text { to } \\
2.7 \text { in women and from } 3.8 \text { to } 3.3 \\
\text { in men } \\
\text { Shorter life expectancy with } \\
\text { earlier-onset DM }\end{array}$ \\
\hline
\end{tabular}


Table 2 (continued)

\begin{tabular}{|c|c|c|c|c|c|c|}
\hline Country & Study & Year & Data & Denominator & Numerator & Findings \\
\hline Australia & Sacre [14] & 2002-2014 & $\begin{array}{l}\text { National } \\
\text { diabetes } \\
\text { registry }\end{array}$ & $\begin{array}{l}\text { People with T2DM } \\
\quad(1,268,018)\end{array}$ & $\begin{array}{l}\text { Age-standardised } \\
\text { mortality (all-cause } \\
\text { and DM-specific) }\end{array}$ & $\begin{array}{l}\text { Declines of } 1.3-2.2 \% \text { points } \\
\text { per year } \\
\text { Declines more pronounced in } \\
\text { middle and older ages } \\
\text { All-cause, CVD and cancer deaths } \\
\text { declined } \\
\text { Pneumonia mortality remained } \\
\text { stable }\end{array}$ \\
\hline $\begin{array}{l}\text { New } \\
\text { Zealand }\end{array}$ & $\mathrm{Yu}[16]$ & 1994-2018 & $\begin{array}{l}\text { National } \\
\text { primary care } \\
\text { database }\end{array}$ & $\begin{array}{l}\text { People with T2DM } \\
\quad(45,072)\end{array}$ & $\begin{array}{l}\text { Age-standardised } \\
\text { mortality (all-cause } \\
\text { and DM-specific) }\end{array}$ & $\begin{array}{l}\text { Increased (per } 1000 \text { person-years) } \\
\text { from } 12.6 \text { before } 1998 \text { to } 19.4 \text { in } \\
1999-2003 \text {, and then decreased } \\
\text { to } 9.9 \text { per } 1000 \text { person-years in } \\
2014-2018\end{array}$ \\
\hline Global & Ling [6] & $2000-2016$ & $\begin{array}{l}\text { WHO } \\
\text { mortality } \\
\text { database }\end{array}$ & $\begin{array}{l}\text { People with T1DM, } \\
\text { T2DM or other } \\
\text { DM from } 108 \\
\text { countries } \\
(7,108,145 \\
\text { deaths) }\end{array}$ & $\begin{array}{l}\text { Mortality rates due to } \\
\text { renal, ophthalmic, } \\
\text { neurological and } \\
\text { peripheral circulatory } \\
\text { complications }\end{array}$ & $\begin{array}{l}\text { Increased from } 46.0 \text { to } 60.2 \text { per } \\
100,000 \text { individuals }(30.8 \%) \text { in } \\
\text { both men and women } \\
\text { Increased in T2DM and decreased } \\
\text { in T1DM } \\
\text { Higher for renal, neurological and } \\
\text { peripheral circulatory } \\
\text { complications } \\
\text { Increased in all except Asia and } \\
\text { South America (declined) }\end{array}$ \\
\hline Global & Zaccardi [7] & $2000-2014$ & $\begin{array}{l}\text { WHO } \\
\text { mortality } \\
\text { database }\end{array}$ & People with DM & $\begin{array}{l}\text { Total and } \\
\text { hypoglycaemia- } \\
\text { related mortality }\end{array}$ & $\begin{array}{l}\text { Increases (per 100,000 individuals) } \\
\text { in total (from 912.5 to 1018.8) } \\
\text { and hypoglycaemia-related } \\
\text { deaths (from } 654 \text { to } 1248 \text { ) } \\
\text { Lowest and declining rates in } \\
\text { Europe, USA, Canada, Japan, NZ } \\
\text { and Australia }\end{array}$ \\
\hline
\end{tabular}

The literature included is composed of articles that reported data with international, national or at least subnational coverage and data sources such as registries or administrative/discharge records. This table does not include publications up to 2015 and is intended as an update to prior reviews [3]

DM, diabetes mellitus; NZ, New Zealand; T1DM, type 1 diabetes mellitus; T2DM, type 2 diabetes mellitus

The data in our review are similar to those in the previous review, which included data published through 2015 [3]; however, our study had notably fewer data from Scandinavia. Our findings also align with other literature showing that as rates of macrovascular complications and mortality have declined over the past three decades [3, 18], there have been increases in complications such as cancer, dementia, infection, tuberculosis and tropical diseases $[3,11$, $19,20]$. Since the largest declines in vascular complications have been observed for older adults, these emerging complications have been more closely observed in this age group. For younger groups, cardiometabolic risk profiles have not improved in HICs [21, 22] or LMICs [23], and previous data show that the rates of vascular complications did not decline as much in younger adults as in middle- or older-age adults [18]. High and increasing diabetes complications and mortality rates observed also align with data showing major gaps in care for adults with diabetes in LMICs [23, 24]. Newer data in this review did not explore whether changes in rates of vascular complications differ by age group or whether these remain the dominant outcomes observed in this younger adult population subgroup. There could also be other reasons for the observed trends, which we discuss below.

\section{How definitions of denominators can influence rates}

Complications The denominators of published complications rates in people with type 2 diabetes are generally from population-based data on adults with diagnosed diabetes. Several factors could have influenced these rates.

Changes in diagnostic thresholds for type 2 diabetes may have influenced the pool of adults with diagnosed diabetes. In 1997, the ADA lowered the threshold for diagnosis of diabetes from a fasting glucose of $7.8 \mathrm{mmol} / \mathrm{l}(140 \mathrm{mg} / \mathrm{dl})$ to $7.0 \mathrm{mmol} / \mathrm{l}$ 
$(126 \mathrm{mg} / \mathrm{dl})$ [25]. This lower threshold may mean that the characteristics of people with newly diagnosed diabetes have changed over time. In other words, sociodemographic and clinical characteristics of adults with type 2 diabetes today differ from those several decades ago. For example, in HICs, higher proportions of today's adults with diabetes represent different race/ethnic groups, lower socioeconomic classes and higher obesity segments than in decades past.

The use of $\mathrm{HbA}_{1 \mathrm{c}}$ for diagnosis of diabetes could have also influenced trends. Recommended by the ADA in 2010 [26, 27], $\mathrm{HbA}_{1 \mathrm{c}}$ was adopted as a diagnostic test by the $\mathrm{WHO}$ and other major diabetes organisations across the globe. $\mathrm{HbA}_{1 \mathrm{c}}$ can simplify the diagnosis of diabetes, as it is a non-fasting test and it can be combined with fasting glucose to make a diagnosis at a single clinic visit [28]. However, in many populations, the $48 \mathrm{mmol} / \mathrm{mol}(6.5 \%) \mathrm{HbA}_{1 \mathrm{c}}$ threshold is more specific and captures a smaller segment of the population as compared with fasting plasma glucose $\geq 7.0 \mathrm{mmol} / 1$ (126 mg/ $\mathrm{dl}$ ); thus, a large-scale shift to screening and diagnosis with $\mathrm{HbA}_{1 \mathrm{c}}$ could mean reduced diabetes detection (and incidence) in those tested this way. On the other hand, increased testing could increase diagnoses if it is easier to use $\mathrm{HbA}_{1 \mathrm{c}}$ and fasting glucose in combination (or $\mathrm{HbA}_{1 \mathrm{c}}$ alone for screening) than two consecutive fasting plasma glucose tests. Trends in actual screening and diagnostic practices within healthcare systems are not well documented.

The proportion of those remaining undiagnosed in the total population with diabetes varies substantially globally and influences the denominators for rates of complications and mortality [1, 29]. For example, estimates from the USA [30], Mexico City [31] and cities in South Asia [32] report that $15 \%, 30 \%$ and $26 \%$, respectively, of adults with diabetes are undiagnosed. The proportion of individuals that are undiagnosed might not be a very sensitive indicator of population detection, especially if diabetes prevalence is increasing. More direct population-level information on diabetes testing and how diabetes is identified in practice (e.g. using glucose tests, $\mathrm{HbA}_{1 \mathrm{c}}$ or a combination thereof) is needed to improve our understanding of how diagnostic practices have influenced trends in diabetes burden [28, 30,33].

The clinical characteristics of the population with diabetes over time could have also influenced trends in complications and mortality rates. The burden of co-existing risk factors (e.g. hypertension and high cholesterol), BMI, use of medications (e.g. angiotensin-modifying agents, statins) and achieving risk factor targets (e.g. $\mathrm{HbA}_{1 \mathrm{c}}<53 \mathrm{mmol} / \mathrm{mol}$ [7.0\%], not smoking) are all relevant. Studies in HIC settings [21, 34, 35 ] have documented increases in achievement of diabetes care goals, with recent declines noted, especially in older adults [22]. Meanwhile, a few studies in LMICs have noted stagnant [32] or worsening cardiometabolic indicators in adults with known diabetes. The widespread use of statins and BP-lowering therapies and reductions in tobacco use have also occurred in the general population without diabetes, resulting in flattening or reductions in cholesterol levels and BP worldwide [36, 37]. In some countries, like in the USA, those with diabetes have still benefited more than the general population in terms of cardiometabolic profile improvements [38]. Detection earlier in the natural history of diabetes may have led to earlier care initiation and therefore lowered rates of complications and mortality in those with diabetes; however, there are few data quantifying these influences.

To understand the potential impact of earlier detection of diabetes, we can examine trends in retinopathy, which can be detected non-invasively using fundus photography, as an indirect indicator of the population-level effects of screening for diabetes. Data from the 1970s and 1980s in the UK suggested a high prevalence of retinopathy (e.g. 36\%) among adults with newly diagnosed type 2 diabetes [39]. More recent data from different but comparable populations suggest a much lower prevalence of retinopathy at the time of diabetes onset: $13 \%$ with retinopathy in a large European study (2007-2008), which included milder forms of the disease [40]; $13 \%$ in a Danish cohort of individuals with incident diabetes (2010 2016) [41]; $18 \%$ in a cohort from Hong Kong (2006-2009) [42]; and $12 \%$ in a national survey in the USA (1999-2018) [43]. The decrease in prevalence of retinopathy at diabetes diagnosis between these studies could be an indication that diabetes is being identified earlier in the disease process.

Mortality The preferred approach to estimating the composition and contribution of diabetes to mortality is through using population registries and other administrative datasets or epidemiological cohorts to identify a denominator of people with diabetes (whether diagnosed, undiagnosed or both). Via surveillance efforts, mortality and causes of death can be directly evaluated in the population. These data can be used to calculate annual death rates among adults with diabetes as well as the excess risk vs those without diabetes. Published estimates using this approach are limited to North America, Europe, high-income Asian countries and Australia; there are no comparable data in LMICs.

Mortality rates from epidemiological cohorts and diabetes registries can be influenced by screening and diagnostic practices. That is, mortality improvements will be observed if diabetes is captured earlier in the disease process over time. Thus, caution is advised when trying to infer whether mortality declines are due to interventions, programmes or policy, as a larger and/or healthier denominator of people with diabetes can also contribute to declining trends. Trends in excess mortality due to diabetes (i.e. the ratio of mortality rates in people with diabetes over those without diabetes) may be helpful in identifying whether the trends in the diabetes population are occurring faster [11], slower or at the same pace [13], as declines in mortality rates have also been noted in general populations without diabetes. 


\section{How case definitions of numerators can influence rates}

The ways in which diabetes complications or mortality are defined in the numerators of published rates over time also influences our understanding of trends.

Complications Diabetes complications are routinely identified in healthcare data from information documented in electronic medical records or administrative claims to nationalised health payers or private insurance companies. The potential pitfalls of these data are that case definitions vary; they are reliant on coding by clinicians, which differs in detail, accuracy and reliability. Coding practices are also affected by national or state policies, regulations and incentives [44]. Some datasets permit, while others restrict, linkage with other datasets or linkage from year to year. This influences the interpretation of estimates: in other words, are these the same individuals with multiple visits and discharges for the same reason or are these many individuals with single episodes of care?

There is also variation in how diabetes complications are defined, both by the clinician coding their diagnoses and by the analysts generating estimates. For example, acute coronary events may be defined by any combination of clinical symptoms, elevated biochemical markers (e.g. troponins), ECG abnormalities, angiography and/or imaging. Sensitivity analyses can help assess the robustness of estimates when using a range of definitions [45], but greater standardisation in how diabetes complications are defined from clinical and administrative data would help ensure comparability of data across regions and globally.

A major concern for LMICs is that administrative data are often not used to estimate diabetes-related complications rates. This is often due to a lack of data availability, representativeness, access, timeliness, usability and/or capacity to process and analyse administrative and clinical data. As a result, in LMICs, most estimates of diabetes complications are from surveys in which outcomes are self-reported or modelled using transition probabilities (i.e. relative risks of complications) from HIC data.

Mortality As mentioned earlier, one approach to estimating mortality rates is based on death certificates with diabetes coded as an underlying or contributing cause. This is challenging as most deaths in people with diabetes are not due to a direct diabetes-specific cause such as diabetic ketoacidosis or hyperglycaemic hyperosmolar syndrome. Coding of causes of death varies by setting, time and population because of differences in awareness or subjective opinions about the role of diabetes in death. As such, there are concerns about inaccurate coding of diabetes as a cause of death. There may also be systematic differences across socioeconomic status and race/ethnicity in how deaths are coded. It is unclear how frequently coding practices and misclassification of diabetesrelated deaths influence diabetes mortality rates. Using diabetes as an underlying cause of death to estimate mortality may also be influenced by diabetes prevalence and diabetes awareness. Studies that use national vital statistics generally report increasing diabetes mortality rates over time. This might explain why mortality rates in LMICs were increasing: the observed trends may represent a problematic method of estimation and increases in diabetes prevalence and not higher diabetes-related mortality per se.

Because of differences in how mortality rates are typically estimated in HICs and LMICs, the WHO and IDF estimate deaths by using models that are based on the prevalence of diabetes and age-specific relative risks of death associated with diabetes. Recent analyses from the IDF indicate that $7 \%, 12 \%$ and $10 \%$ of deaths in low-, middle- and highincome countries, respectively, are due to diabetes [46]. This approach is more generalisable across populations since both the denominators and numerators have biases. With regard to relative risks, we observed that HICs have experienced a narrowing of excess risk of complications and mortality conferred by diabetes compared with those without diabetes; there were no comparable data available from LMICs.

\section{Conclusions and recommendations}

Over the past two decades, annual rates of type 2 diabetesrelated vascular complications and mortality have been declining in HICs, with persistently high burdens experienced by certain underrepresented and indigenous race/ethnic population subgroups. There were no data for renal, ophthalmic, hepatic or neurological disorders associated with diabetes. Surveillance data for LMICs were either available in few countries or not comparable with data from HICs; this is a critical knowledge gap that must be addressed. If reductions in mortality in people with diabetes become more widespread and are coupled with growth in diabetes prevalence, it is likely that the lifetime accumulation of type 2 diabetes complications and morbidities will grow worldwide [47-49]. It is also possible that with better treatments and management of cardiovascular risk factors, a variety of non-vascular complications for which diabetes is a risk factor (e.g. dementia or infections such as cellulitis and pneumonia) will become relatively more important in individuals with diabetes.

To improve measurement and interpretation of trends in type 2 diabetes complications and mortality rates worldwide, we offer several recommendations (Table 3). First, stronger surveillance infrastructure in LMICs is needed. A comprehensive approach would involve establishing population-level registries that can be linked to hospital discharge data (for complications) and vital statistics data (for cause-specific and excess mortality estimation). This will require 
Table 3 Recommendations to improve estimation and interpretation of diabetes burdens

\begin{tabular}{|c|c|}
\hline Category & Benefits \\
\hline \multicolumn{2}{|l|}{ Data infrastructure } \\
\hline Enhance vital statistics coverage & Decreases biases related to where deaths occur \\
\hline Enable linkage between community, healthcare and vital registration data systems & Increases validity of reported events \\
\hline \multicolumn{2}{|l|}{ Denominators and numerators } \\
\hline Validate consensus definitions for diabetes and disseminate & $\begin{array}{l}\text { Improves understanding of screening and diagnostic practices } \\
\text { and their influence on rates }\end{array}$ \\
\hline Expand and standardise routine collection and use of data from healthcare settings & $\begin{array}{l}\text { Adds more credible biochemical and clinician-coded } \\
\text { indicators to self-reported data }\end{array}$ \\
\hline $\begin{array}{l}\text { Develop classification structure for diabetes complications (traditional, emerging and } \\
\text { other comorbidities) }\end{array}$ & $\begin{array}{l}\text { Elevates importance of non-fatal and non-traditional diabetes } \\
\text { complications that affect quality of life }\end{array}$ \\
\hline Establish denominators based on standardised definitions & $\begin{array}{l}\text { Permits credible comparison of trends within and across } \\
\text { countries }\end{array}$ \\
\hline \multicolumn{2}{|l|}{ Analysis } \\
\hline Expand capacity to manage data and analyses (especially in LMICs) & $\begin{array}{l}\text { Improves surveillance of diabetes burdens and impacts of } \\
\text { policies and programmes }\end{array}$ \\
\hline \multicolumn{2}{|l|}{ Reporting } \\
\hline $\begin{array}{l}\text { Standardise chronic disease surveillance reporting through checklists that recommend } \\
\text { providing critical contextual information regarding case definitions and how these } \\
\text { are operationalised in the data }\end{array}$ & $\begin{array}{l}\text { Helps analysts and users of data to contextualise and compare } \\
\text { the findings }\end{array}$ \\
\hline
\end{tabular}

governmental investments and efforts by national statistics bureaus to improve the completeness of death certification and cause-of-death assessments and might be especially challenging in rural parts of the world where most deaths occur in non-healthcare settings. Ensuring that registries have a longitudinal component assures a population-based cohort infrastructure that is less subject to biases. That said, in resourceconstrained settings, investing in epidemiological cohorts may be an alternative that offers valuable information. However, most cohorts are subject to selection bias and may require periodic expansion (e.g. age period birth cohorts) and sustained investments to provide some semblance of population monitoring and trends.

Second, standardised epidemiological approaches to defining type 1 and type 2 diabetes are needed that balance feasibility, accuracy and precision. This would involve documenting the type and timing (simultaneous or consecutive) of diabetes testing, coding of medications and algorithms that help distinguish diabetes subtypes. This will also open opportunities for more research into types of diabetes testing that are commonly implemented in practice and if and how these influence detection and related care and interventions that follow. Standardising epidemiological definitions of diabetes complications is also important.

Third, focused capacity strengthening is needed in LMICs to build and sustain data management and analytical expertise. This can contribute to more harmonised and comparable estimates of diabetes burdens globally as well as provide opportunities to evaluate the impacts of detection and prevention and management policies and programmes locally and nationally.
Fourth, we propose the development, wider dissemination and implementation of guidelines regarding surveillance reporting; the minimum elements that should be included in the published literature can elevate the credibility and comparability of data globally. A recent guide from the IDF [50] regarding conduct of epidemiological surveys for diabetes addresses reporting standards and offers an exemplar.

Together, these recommendations can advance interpretation and use of international trend data for monitoring and intervention in type 2 diabetes complications and mortality rates.

Authors' relationships and activities ES is a member of the Diabetologia Editorial Board. MKA reports a grant to Emory University from Merck and Co. that is outside the scope of the submitted work. JP-S is partner and head of health analytics of Lane Clark \& Peacock LLP and vice-chair of the Royal Society for Public Health and reports personal fees from Novo Nordisk A/S and Pfizer Ltd., all outside of the submitted work.

The other authors declare that there are no relationships or activities that might bias, or be perceived to bias, their work.

Contribution statement MKA was responsible for drafting the article, and all authors revised it critically for important intellectual content. All authors approved the version to be published.

Open Access This article is licensed under a Creative Commons Attribution 4.0 International License, which permits use, sharing, adaptation, distribution and reproduction in any medium or format, as long as you give appropriate credit to the original author(s) and the source, provide a link to the Creative Commons licence, and indicate if changes were made. The images or other third party material in this article are included in the article's Creative Commons licence, unless indicated otherwise in a credit line to the material. If material is not included in 
the article's Creative Commons licence and your intended use is not permitted by statutory regulation or exceeds the permitted use, you will need to obtain permission directly from the copyright holder. To view a copy of this licence, visit http://creativecommons.org/licenses/by/4.0/.

\section{References}

1. International Diabetes Federation (2019) IDF Diabetes Atlas 9th Edition. Available from https://www.diabetesatlas.org/en/. Accessed Feb 152020

2. NCD Risk Factor Collaboration (2016) Worldwide trends in diabetes since 1980: a pooled analysis of 751 population-based studies with 4.4 million participants. Lancet 387(10027):1513-1530. https://doi.org/10.1016/S0140-6736(16)00618-8

3. Harding JL, Pavkov ME, Magliano DJ, Shaw JE, Gregg EW (2019) Global trends in diabetes complications: a review of current evidence. Diabetologia 62(1):3-16. https://doi.org/10.1007/ s00125-018-4711-2

4. NCD Countdown Collaborators (2018) NCD countdown 2030: worldwide trends in non-communicable disease mortality and progress towards sustainable development goal target 3.4. Lancet 392(10152):1072-1088. https://doi.org/10.1016/s0140-6736(18) 31992-5

5. Lin X, Xu Y, Pan X et al (2020) Global, regional, and national burden and trend of diabetes in 195 countries and territories: an analysis from 1990 to 2025. Sci Rep 10(1):14790. https://doi.org/ 10.1038/s41598-020-71908-9

6. Ling W, Huang Y, Huang YM, Fan RR, Sui Y, Zhao HL (2020) Global trend of diabetes mortality attributed to vascular complications, 2000-2016. Cardiovasc Diabetol 19(1):182. https://doi.org/ 10.1186/s12933-020-01159-5

7. Zaccardi F, Dhalwani NN, Webb DR, Davies MJ, Khunti K (2018) Global burden of hypoglycaemia-related mortality in 109 countries, from 2000 to 2014: an analysis of death certificates. Diabetologia 61(7):1592-1602. https://doi.org/10.1007/s00125-018-4626-y

8. Malhão TA, Brito Ados S, Pinheiro RS, Cabral Cda S, Camargo TM, Coeli CM (2016) Sex differences in diabetes mellitus mortality trends in Brazil, 1980-2012. PLoS One 11(6):e0155996. https://doi. org/10.1371/journal.pone.0155996

9. Nojilana B, Bradshaw D, Pillay-van Wyk V et al (2016) Emerging trends in non-communicable disease mortality in South Africa, 1997 - 2010. S Afr Med J 106(5):58. https://doi.org/10.7196/ SAMJ.2016.v106i5.10674

10. Sarfo-Kantanka O, Sarfo FS, Oparebea Ansah E, Eghan B, AyisiBoateng NK, Acheamfour-Akowuah E (2016) Secular trends in admissions and mortality rates from diabetes mellitus in the Central Belt of Ghana: a 31-year review. PLoS One 11(11): e0165905. https://doi.org/10.1371/journal.pone.0165905

11. Gregg EW, Cheng YJ, Srinivasan M et al (2018) Trends in causespecific mortality among adults with and without diagnosed diabetes in the USA: an epidemiological analysis of linked national survey and vital statistics data. Lancet 391(10138):2430-2440. https://doi.org/10.1016/s0140-6736(18)30314-3

12. Wu H, Lau ESH, Ma RCW et al (2020) Secular trends in all-cause and cause-specific mortality rates in people with diabetes in Hong Kong, 2001-2016: a retrospective cohort study. Diabetologia 63(4): 757-766. https://doi.org/10.1007/s00125-019-05074-7

13. Pearson-Stuttard J, Bennett J, Cheng YJ et al (2021) Trends in predominant causes of death in individuals with and without diabetes in England from 2001 to 2018: an epidemiological analysis of linked primary care records. Lancet Diabetes Endocrinol 9(3):165173. https://doi.org/10.1016/s2213-8587(20)30431-9

14. Sacre JW, Harding JL, Shaw JE, Magliano DJ (2021) Declining mortality in older people with type 2 diabetes masks rising excess risks at younger ages: a population-based study of all-cause and cause-specific mortality over 13 years. Int J Epidemiol 50(4): 1362-1372. https://doi.org/10.1093/ije/dyaa270

15. Lanting LC, Joung IMA, Mackenbach JP, Lamberts SWJ, Bootsma AH (2005) Ethnic differences in mortality, end-stage complications, and quality of care among diabetic patients: a review. Diabetes Care 28(9):2280-2288. https://doi.org/10.2337/diacare. 28.9.2280

16. Yu D, Zhao Z, Osuagwu UL et al (2021) Ethnic differences in mortality and hospital admission rates between Māori, Pacific, and European new Zealanders with type 2 diabetes between 1994 and 2018: a retrospective, population-based, longitudinal cohort study. Lancet Glob Health 9(2):e209-e217. https://doi.org/10. 1016/S2214-109X(20)30412-5

17. Centers for Disease Control and Prevention (2017) Native Americans with Diabetes. Available from https://www.cdc.gov/ vitalsigns/aian-diabetes/index.html. Accessed July 2021

18. Gregg EW, Li Y, Wang J et al (2014) Changes in diabetes-related complications in the United States, 1990-2010. N Engl J Med 370(16):1514-1523. https://doi.org/10.1056/NEJMoa1310799

19. Harding JL, Benoit SR, Gregg EW, Pavkov ME, Perreault L (2020) Trends in rates of infections requiring hospitalization among adults with versus without diabetes in the U.S., 2000-2015. Diabetes Care 43(1):106-116. https://doi.org/10.2337/dc19-0653

20. Pearson-Stuttard J, Zhou B, Kontis V, Bentham J, Gunter MJ, Ezzati M (2018) Worldwide burden of cancer attributable to diabetes and high body-mass index: a comparative risk assessment. Lancet Diabetes Endocrinol 6(6):e6-e15. https://doi.org/10.1016/ S2213-8587(18)30150-5

21. Ali MK, Bullard KM, Saaddine JB, Cowie CC, Imperatore G, Gregg EW (2013) Achievement of goals in U.S. diabetes care, 1999-2010. N Engl J Med 368(17):1613-1624. https://doi.org/10. 1056/NEJMsa1213829

22. Fang M, Wang D, Coresh J, Selvin E (2021) Trends in diabetes treatment and control in U.S. adults, 1999-2018. N Engl J Med 384(23):2219-2228. https://doi.org/10.1056/NEJMsa2032271

23. Flood D, Seiglie JA, Dunn M et al (2021) The state of diabetes treatment coverage in 55 low-income and middle-income countries: a cross-sectional study of nationally representative, individual-level data in 680,102 adults. Lancet Healthy Longevity 2(6):e340-e351. https://doi.org/10.1016/S2666-7568(21)00089-1

24. Manne-Goehler J, Geldsetzer P, Agoudavi K et al (2019) Health system performance for people with diabetes in 28 low- and middle-income countries: a cross-sectional study of nationally representative surveys. PLoS Med 16(3):e1002751. https://doi. org/10.1371/journal.pmed.1002751

25. The Expert Committee on the Diagnosis and Classification of Diabetes Mellitus (1997) Report of the expert committee on the diagnosis and classification of diabetes mellitus. Diabetes Care 20(7):1183-1197. https://doi.org/10.2337/diacare.20.7.1183

26. The International Expert Committee (2009) International expert committee report on the role of the A1C assay in the diagnosis of diabetes. Diabetes Care 32(7):1327-1334. https://doi.org/10.2337/ dc09-9033

27. American Diabetes Association (2010) Standards of medical Care in Diabetes-2010. Diabetes Care 33(Supplement 1):S11-S61. https://doi.org/10.2337/dc10-S011

28. Selvin E, Wang D, Matsushita K, Grams ME, Coresh J (2018) Prognostic implications of single-sample confirmatory testing for undiagnosed diabetes: a prospective cohort study. Ann Intern Med 169(3):156-164. https://doi.org/10.7326/m18-0091

29. Beagley J, Guariguata L, Weil C, Motala AA (2014) Global estimates of undiagnosed diabetes in adults. Diabetes Res Clin Pract 103(2):150-160. https://doi.org/10.1016/j.diabres.2013.11.001

30. Selvin E, Wang D, Lee AK, Bergenstal RM, Coresh J (2017) Identifying trends in undiagnosed diabetes in U.S. adults by using 
a confirmatory definition: a cross-sectional study. Ann Intern Med 167(11):769-776. https://doi.org/10.7326/m17-1272

31. Alegre-Diaz J, Herrington W, Lopez-Cervantes M et al (2016) Diabetes and cause-specific mortality in Mexico City. N Engl J Med 375(20):1961-1971. https://doi.org/10.1056/ NEJMoa1605368

32. Anjana RM, Deepa M, Subashini R et al (2021) Temporal changes in diabetes prevalence and achievement of care goals in urban South Asia from 2010 to 2016 - the Center for Cardio-metabolic Risk Reduction in South Asia study. Diabet Med 38(2):e14424. https://doi.org/10.1111/dme.14424

33. Selvin E, Crainiceanu CM, Brancati FL, Coresh J (2007) Shortterm variability in measures of glycemia and implications for the classification of diabetes. Arch Intern Med 167(14):1545-1551. https://doi.org/10.1001/archinte.167.14.1545

34. Stone MA, Charpentier G, Doggen K et al (2013) Quality of care of people with type 2 diabetes in eight European countries: findings from the guideline adherence to enhance care (GUIDANCE) study. Diabetes Care 36(9):2628-2638. https://doi.org/10.2337/dc121759

35. Shin JI, Wang D, Fernandes G et al (2021) Trends in receipt of American Diabetes Association guideline-recommended care among U.S. adults with diabetes: NHANES 2005-2018. Diabetes Care 44(6):1300-1308. https://doi.org/10.2337/dc20-2541

36. Danaei G, Finucane MM, Lin JK et al (2011) National, regional, and global trends in systolic blood pressure since 1980: systematic analysis of health examination surveys and epidemiological studies with 786 country-years and 5.4 million participants. Lancet 377(9765):568-577. https://doi.org/10.1016/S0140-6736(10) 62036-3

37. Farzadfar F, Finucane MM, Danaei G et al (2011) National, regional, and global trends in serum total cholesterol since 1980: systematic analysis of health examination surveys and epidemiological studies with 321 country-years and 3.0 million participants. Lancet 377(9765):578-586. https://doi.org/10.1016/S01406736(10)62038-7

38. Ali MK, Bullard KM, Saydah S, Imperatore G, Gregg EW (2018) Cardiovascular and renal burdens of prediabetes in the USA: analysis of data from serial cross-sectional surveys, 1988-2014. Lancet Diabetes Endocrinol 6(5):392-403. https://doi.org/10.1016/S22138587(18)30027-5

39. UK Prospective Diabetes Study (UKPDS) Group (1998) Intensive blood-glucose control with sulphonylureas or insulin compared with conventional treatment and risk of complications in patients with type 2 diabetes (UKPDS 33). Lancet (London, England) 352(9131):837-853

40. Ponto KA, Koenig J, Peto T et al (2016) Prevalence of diabetic retinopathy in screening-detected diabetes mellitus: results from the Gutenberg health study (GHS). Diabetologia 59(9):19131919. https://doi.org/10.1007/s00125-016-4013-5

41. Gedebjerg A, Almdal TP, Berencsi K et al (2018) Prevalence of micro- and macrovascular diabetes complications at time of type 2 diabetes diagnosis and associated clinical characteristics: a crosssectional baseline study of 6958 patients in the Danish DD2 cohort. J Diabetes Complicat 32(1):34-40. https://doi.org/10.1016/j. jdiacomp.2017.09.010

42. Lee KM, Sum WM (2011) Prevalence of diabetic retinopathy in patients with recently diagnosed diabetes mellitus. Clin Exp Optom 94(4):371-375. https://doi.org/10.1111/j.1444-0938.2010.00574.x

43. Fang M, Selvin E (2021) Thirty-year trends in complications in U.S. adults with newly diagnosed type 2 diabetes. Diabetes Care 44(3):699-706. https://doi.org/10.2337/dc20-2304

44. Hashimoto RE, Brodt ED, Skelly AC, Dettori JR (2014) Administrative database studies: goldmine or goose chase? Evid Based Spine Care J 5(2):74-76. https://doi.org/10.1055/s-00341390027
45. Leong A, Dasgupta K, Bernatsky S, Lacaille D, Avina-Zubieta A, Rahme E (2013) Systematic review and meta-analysis of validation studies on a diabetes case definition from health administrative records. PLoS One 8(10):e75256. https://doi.org/10.1371/journal. pone. 0075256

46. Saeedi P, Salpea P, Karuranga S et al (2020) Mortality attributable to diabetes in 20-79 years old adults, 2019 estimates: Results from the International Diabetes Federation Diabetes Atlas, 9(th) edition. Diabetes Res Clin Pract 108086. https://doi.org/10.1016/j.diabres. 2020.108086

47. Gregg EW, Zhuo X, Cheng YJ, Albright AL, Narayan KMV, Thompson TJ (2014) Trends in lifetime risk and years of life lost due to diabetes in the USA, 1985-2011: a modelling study. Lancet Diabetes Endocrinol 2(11):867-874. https://doi.org/10.1016/ S2213-8587(14)70161-5

48. Muschik D, Tetzlaff J, Lange K, Epping J, Eberhard S, Geyer S (2017) Change in life expectancy with type 2 diabetes: a study using claims data from lower Saxony, Germany. Popul Health Metrics 15(1):5. https://doi.org/10.1186/s12963-017-0124-6

49. Bardenheier BH, Lin J, Zhuo X et al (2016) Disability-free lifeyears lost among adults aged $>/=50$ years with and without diabetes. Diabetes Care 39(7):1222-1229. https://doi.org/10.2337/dc151095

50. Aschner P, Basit A, Fawwad A et al (2021) IDF Guide for Diabetes Epidemiology Studies. Available from https://idf.org/our-activities/ epidemiology-research/idf-guide-for-diabetes-epidemiologystudies.html. Accessed 30 June 2021

51. Cai M, Xie Y, Bowe B et al (2021) Temporal trends in incidence rates of lower extremity amputation and associated risk factors among patients using veterans health administration services from 2008 to 2018. JAMA Netw Open 4(1):e2033953. https://doi.org/ 10.1001/jamanetworkopen.2020.33953

52. An J, Nichols GA, Qian L et al (2021) Prevalence and incidence of microvascular and macrovascular complications over 15 years among patients with incident type 2 diabetes. BMJ Open Diabetes Res Care 9(1):e001847. https://doi.org/10.1136/bmjdrc-2020001847

53. López-de-Andrés A, Albaladejo-Vicente R, Palacios-Ceña D et al (2020) Time trends in Spain from 2001 to 2018 in the incidence and outcomes of hospitalization for urinary tract infections in patients with type 2 diabetes mellitus. Int J Environ Res Public Health 17(24):9427. https://doi.org/10.3390/ijerph17249427

54. Orozco-Beltrán D, Guillen-Mollá A, Cebrián-Cuenca AM et al (2021) Hospital admissions trends for severe hypoglycemia in diabetes patients in Spain, 2005 to 2015. Diabetes Res Clin Pract 171:108565. https://doi.org/10.1016/j.diabres.2020.108565

55. Ramalho A, Lobo M, Duarte L, Souza J, Santos P, Freitas A (2020) Landscapes on prevention quality indicators: a spatial analysis of diabetes preventable hospitalizations in Portugal (2016-2017). Int J Environ Res Public Health 17(22):8387. https://doi.org/10.3390/ ijerph 17228387

56. Park JH, Ha KH, Kim BY, Lee JH, Kim DJ (2021) Trends in cardiovascular complications and mortality among patients with diabetes in South Korea. Diabetes Metab J 45(1):120-124. https:// doi.org/10.4093/dmj.2020.0175

57. You JH, Song SO, Park SH et al (2019) Trends in hyperglycemic crisis hospitalizations and in- and out-of-hospital mortality in the last decade based on Korean National Health Insurance Claims Data. Endocrinol Metab (Seoul) 34(3):275-281. https://doi.org/ 10.3803/EnM.2019.34.3.275

58. Kim J, Chun DI, Kim S et al (2019) Trends in lower limb amputation in patients with diabetic foot based on vascular intervention of peripheral arterial disease in Korea: a population-based Nationwide study. J Korean Med Sci 34(26):e178. https://doi.org/10.3346/ jkms.2019.34.e178 
59. Wu H, Yang A, Lau ESH et al (2020) Secular trends in rates of hospitalisation for lower extremity amputation and 1 year mortality in people with diabetes in Hong Kong, 2001-2016: a retrospective cohort study. Diabetologia 63(12):2689-2698. https://doi.org/10. 1007/s00125-020-05278-2

60. Lin CW, Armstrong DG, Lin CH et al (2019) Nationwide trends in the epidemiology of diabetic foot complications and lowerextremity amputation over an 8-year period. BMJ Open Diabetes Res Care 7(1):e000795. https://doi.org/10.1136/bmjdrc-2019000795

61. Florêncio RB, de Araújo Fonseca LG, da Silva VFD, Lima ÍNDF, Gualdi LP (2021) Diabetes mellitus hospitalization and mortality rate according to a national database in Brazil: a longitudinal study. BMC Public Health 21(1):403. https://doi.org/10.1186/s12889021-10438-Z

62. Klafke A, Duncan BB, Stevens A et al (2015) The decline in mortality due to acute complications of diabetes mellitus in Brazil, 1991-2010. BMC Public Health 15:772. https://doi.org/10. 1186/s12889-015-2123-5
63. Chaparro-Narváez P, Alvis-Zakzuk NJ, Díaz-Jiménez D, Castañeda-Orjuela C (2021) Trends in diabetes mortality identified from death certificates in Colombia, 1979-2017. Rev Panam Salud Publica 45:e13. https://doi.org/10.26633/rpsp.2021.13

64. Hernández H, Macías G (2017) Time-trend analysis of diabetes mellitus mortality in Argentina, 1990-2013. Rev Panam Salud Publica 41:e73. https://doi.org/10.26633/rpsp.2017.73

65. Li Y, Kou C, Bai W et al (2019) Trends in diabetes mortality by gender in urban and rural areas in China from 2003 to 2012: An age-period-cohort analysis. Asia Pac J Public Health 31(3):238245. https://doi.org/10.1177/1010539519841288

66. Li HY, Wu YL, Tu ST, Hwu CM, Liu JS, Chuang LM (2019) Trends of mortality in diabetic patients in Taiwan: a nationwide survey in 2005-2014. J Formos Med Assoc 118(Suppl 2):S83s89. https://doi.org/10.1016/j.jfma.2019.07.008

Publisher's note Springer Nature remains neutral with regard to jurisdictional claims in published maps and institutional affiliations. 